\title{
The Internet and the Debasement of Women in Ghana
}

\author{
Kwabena Opare Akurang-Parry
}

\begin{abstract}
In the spring of 1998, a radio station in Ghana announced that sixteen Ghanaian women had appeared in the nude on the Internet. Widely discussed in the Ghanaian media, the public reaction to this event seemed to be largely one of shock and moral outrage. The articleaddresses both the responses to and possible causes of this phenomenon, drawing attention to the role of foreign influence and harsh economic conditions in Ghana. The patriarchal nature of the national debate is questioned, raising an alternative perspective on the reality currently faced by Ghanaian women.
\end{abstract}

\section{Précis}

Auprintemps 1998, une station de radio du Ghana annonçait que seize ghanéennes avaient posé nues pour un site Internet. Amplement discutée dans les médias ghanéens, la réaction du publicd cet événement semble avoir étéle choc et l'outrage moral. L'article porte à la fois sur les causes de ce phénomène et sur la réponse dont il a faitl'objet. Il attire l'attention sur le rôle de l'influence étrangère et la dureté des conditions économiques au Ghana. Le ton très patriarcal du débat national sur cette question est pris en considération et suscite unemise en perspective nouvelle des réalités auxquelles font face les femmes ghanéennes.

On the morning of April 14, 1998, Joy $F M$, a popular morning radio talkshow in Accra, the capital city of Ghana, announced that Ghanaian women had posed in the nude on the internet. This led to intense public discussions and commentary in both the independent and government-operated media. The

Kwabena Opare Akurang-Parry, a Post-Doctoral Research Fellow at the York University/ UNESCO Nigerian Hinterland Project in Toronto, is a Ghanaian historian and poet, specializing in colonial and contemporary Africa. widespread discussion drew attention to local economic conditions, and to international tourism and "Westernism" as agencies of moral decline in contemporary Ghanaian society. The state of the Ghanaian women's movement was also called into question, as were concerns about how to best curb endemic gender inequalities and the sexual exploitation of women, at both national and international levels (Abu 1998, 11; Sam 1998, 1 and 6-7; Wereko $1998,7)$.

\section{The Phenomenon: Ghanaian Women Appearing in the Nude on the Internet}

The women who appeared on the Internet included Africans and Asians, with Ghanaian women constituting sixty percent of the African presence. (Free Press, 22 April-28 April 1998, 1 and 12; Wereko 1998, 7). The media revealed that out of " 300 girls of different nationalities ... only the Ghanaian girls posed naked" (Wereko1998,7), and that there were an additional 300 pictures of Ghanaian women on the Internet (Sam $1998,6)$. The nude photos and corresponding names of the women were splashed on the front pages of the April 16th issue of Graphic Showbiz. Despite their criticism of Graphic Showbiz, other newspapers followed suit in publishing the nude pictures and correspondingnames (The Statesman, 26 April 1998, 7). Indicative of the scale of the scandal was the fact that, in addition to detailed discussions in the newspapers and on the radio, the Ghanaian public was able to actually see the nude pictures (Wereko 1998,7).

The Ghanaian women ranged in age from 16 to 30 years. Some of them were "highly educated ... having acquired university education, while the majority were either in school or had just completed secondary school" (Sam 1998,6). The women stated on the Internet that they were "seeking men for good times, long term relationships and even marriage" (ibid.). Responsible for the appearance of the Ghanaian women on the Internet was a syndicate operating out of Agona Swedru, a relatively remote area in the Central Region of Ghana, a location which may have facilitated the clandestine activities.

\section{Response to the Phenomenon}

The subject was publicly discussed, nation-wide (The Statesman, 26 April $1998,7)$. People telephoned radio talk shows to register their "disgust" with the incident and its implications for Ghanaian women. Apart from the discussions in the media, involving both professors and politicians (Buor 1998, 3), Ghanaians freely discussed and debated the problem in public places-at the office, in the markets, on the bus. The general consensus seemed to be that contemporary Ghanaian society "is heading towards a stupendous moral crisis, which normally precedes the collapse of civilizations" (ibid.; see also Abu 1998,11; and Wereko 1998,7). Public opinion concluded that the Ghanaian women had gone beyond the boundaries of common decency and communalmorality.

From the standpoint of the average Ghanaian, the appearance of the women on the Internet was a "scandal" of unimaginable proportions. Theopinion of the moral majority was that the nudity of the Ghanaian women on the Internet had debased Ghanaian womanhood and disgraced the integrity of all Ghanaians (Buor 1998, 3; Abu 1998, 11; The Statesman, 26 April 1998,7). Some observers and social commentators argued that Ghana was experiencing a crisis ofmorality, further exemplified by a spate of reports in the newspapers about the moral turpitude of Ghanaian youth, as well as observations that prostitution, rape and child molestation were on the increase (Wereko 1998, 7; Sam 1998, 1; and Buor 1998, 3). Others

Refuge, Vol.17, No. 5 (November 1998) 
attributed the scandal to a perceived crusading zeal, displayed by Ghanaians, to copy "Western" ways of life. The popular view was that the women's appearance in the nude was "unGhanaian." Many observers opined that the unbridled efforts of Ghanaians to abandon theirculture and normative ways of life was responsible for the moral decay (Abu 1998, 11; Wereko 1998, 7 ).

In addition, popular opinion called for punitive measures to be instituted against the Ghanaian women and all others involved in the scandal, to act as deterrents. Onecommentator wrote that "all efforts should be made to apprehend and prosecute all those involved. If this is treated lightly, worse things will follow" (Abu 1998, 11). Another suggested the syndicate which had "lured" the women "should bear the brunt of the on-going investigation into the matter" (Wereko 1998, 7). While some observers believed that the Ghanaian women were unsuspecting (ibid.), others raised the issue of nudity as evidence of the low morality of the Ghanaian women involved (Abu 1998, 11; and Buor 1998, 3).

The appearance of the Ghanaian women on the Internet was also used to castigate women's groups in Ghana. In the opinion of political commentators, such groups are being used to serve the political needs of the ruling government, instead of working to implement meaningful policies geared towards alleviating the harsh conditions which affect Ghanaian women. Indeed, the effectiveness of the women's movement has been constrained by the control of male patriarchal political structures. Although Nana Konadu Agyeman Rawlings, the First Lady of Ghana, has been instrumental in organizing the women's movement (Novicki 1995,5254), in using the movement to amass support for her husband's political ambitions, she displays incontestable political motivation (Buor 1998, 3). Thus, it was her organization, the 31st DecemberWomen's Movement, which bore the brunt of the criticism. Political pundits jeered, suggesting women's groups had remained silent when their voices wereneeded themost(Abu 1998, 11). The conclusion reached was that "apart from politically motivated demonstrations, women are a bit stale in organizing demonstrations to pressure for authorities to accede to their demands" (Buor 1998, 3).

\section{The Causes}

Although many theories were forwarded, foreign sexual predators and the international sexindustry were pinpointed in the press commentaries and discourses as the most significant forces behind the emergence of trafficking in women on the Internet. Blame was attributed to "a syndicate based in Europe [that] has employed the enormous power of the internet to recruit children to promote sex tourism in some countries" (Wereko 1998,7), raising concerns "related to the impetus the Internet is giving to sex tourism, particularly the incidence of child sex" (ibid.). The public discussions and social commentaries of the moral majority of Ghanaians delineated several major reasons for this conclusion.

Firstly, it was noted that Western currencies possess powerful buying power in Africa, enablingsexual predators from the West to flaunt their wealth, in a quest to attract women and children for sexual purposes. Secondly, the relatively lax administration of laws in Africa acts as a magnetic lure to foreign sexual predators (Free Press, 22 April28 April 1998,4). Sexual predators prefer to operate in foreign countries, where a cloud of anonymity facilitates their clandestine craft. Lastly, bureaucracies and social institutions in Africa are circumscribed by the cumbersome weight of a patriarchy which blames victims, mainly women and children, instead of the male perpetrators. Media discussion strongly suggests that women in the so-called Third World are vulnerable not only to local sexual exploitation and abuse, but are also left increasingly unprotected against global sex tourism and sexual exploitation via the internet (Sam 1998, 1 and 6-7; Wereko 1998, 7).

Furthermore, the public discussions and media commentaries proposed that marriage was a crucial motivation for the Ghanaian women appearing on the Internet. Proof seemed to lie in the fact that the respective addresses of the Ghanaian women were "provided for a fee" (Sam 1998, 6-7; Wereko 1998,7; and Free Press, 22 April-28 April 1998, 1 and 12). Also, ninety percent of the Ghanaian women stated that they were available for marriage or wanted to travel overseas. This raised the issue of a marriage of convenience, or the desire to "get rich quick." The contention exists that, in order to make money, "women who could be of dignity present their bodies nude on the Internet" (Buor 1998, 3). A government-run newspaper, The Daily Graphic, wrote that some foreigners armed with such knowledge "deliberately befriend" Ghanaian women in order to plunder them sexually (Wereko $1998,7)$. Marriage of convenience is seen by some Ghanaian women as a means of gaining social mobility and of improving their lives in a foreign country. Arguably, "Aburokyere," or "the West," has an attractive gleam which transcends gender, class, ethnicity, and age. Many in the so-called Third World believe that migration to and life in the West offers renewed hope and an end to deprivation in their lives. While the Ghanaian women in question may not have understood the import of the Internet, they undoubtedly understood the link between that medium and the West.

Apart from social hardships and material deprivation, the "Hollywood" image created by the West to maintain cultural and economichegemony has a powerful influence. It is this gleam which attracts people from the so-called Third World countries to the West, those who see this constructed paradise as a place where they will feel at home (Abu 1998, 11). Foreigners, as well as Ghanaianmen living abroad, are seen as splendid means by which to access travel abroad, or as a way of making quick money at home. Although scientific data is lacking, a spate of stories abound about Ghanaian women whohave been deceived and emotionally deflated by foreigners and by Ghanaian men living in the West, men taking advantage of

14 
marginalized women whobelieve them to be capable ensuring a good life (Wereko 1998,7).

Implicit in these myths, and also seen as contributing factors to the scandal, are local economic problems, which have been attributed to the IMF-sponsored Structural Adjustment Program (SAP). In popular discourse, the SAP is seen to have exacerbated pre-existing economic hardships and engineered social dislocation (Adams 1995, 34-37).

Such trends have their historical setting. They were unheard of some two decades ago. It cannot be disputed that these evil acts are contemporaneous with economic hardships. Without doubt the introduction of the SAP ... [has] brought in its wake abnormal behaviours as a means of survival. (Buor 1998, 3)

According to Buor, theSAPhas led to labour lay-offs, devaluation of the Ghanaian currency, and an increased cost of living, as well as facilitating endemic nepotism and government corruption. Furthermore, unemployment has skyrocketed and school-leavers cannot find jobs. He argued that "if there is no improvement in the economy to correct such socio-economic malaise, social behaviour worse than this would surface (Buor 1998, 3). In the port cities of Ghana, where holders of foreign currency disembark, female prostitution is growing. Foreigners with Ghanaian agents profit from the effects of the SAP by capitalizing on the scarcity of jobs, luring unsuspecting females with offers of employment overseas. This may well explain the increasing number of African women engaged in prostitution in Europe (Stranberg 1998, 16-17; and Goodwill 1998, 36-38).

\section{The Role of Society in Curbing the Exploitation of Women}

The nudity of the Ghanaian women on the Internet led to numerous calls for action, for the rectification of social problems. One commentator called on

serious men and women with integrity and respect, through word and deed, to ameliorate and eventually put an end to such moral pandemic [sic], and to put the dignity of wom- anhood back on our socjo-cultural landscape. (Buor 1998, 3)

In response to the women's appearance on the Internet, the Ghanaian government proposed measures to combat what it considered a "shameful act." A member of the Council of State, Dr.Mrs. Mary Grant, "condemned the Act and stated that the Council [of State] and the National Council on Women and Development (NCWD) are going to take action about (sic) this disgraceful act by some Ghanaian women" (Free Press, 22 April-28 April 1998, 1 and 12). Furthermore, the Ghanaian Ministry of Communications responsible for regulating the usage and development of the internet "is collating views of major stakeholders for the formulation of a National Communications Policy", to monitor the use of the internet "with the view to protecting the good image of the country" (Wereko 1998, 7).

The government was advised to stop the erosion of Ghanaian culture and the encroachment of foreign ways of life, to implement a national effort to cease the portrayal of "Western standards and behaviour as the epitome of modernism and civilization." Some feared if nothing was done to arrest the tides of "Westernism," the "moral fibre and sense of decency" of Ghanaians would "continue to wear down into irretrievable shreds and threads" (Abu 1998, 11). Ghanaian security forces were told to be more vigilant in policing foreigners. One commentator noted that foreigners ostensibly "befriend our girls to capture their lovemaking scenes on video for the production of pornographic films" (Wereko 1998,7).

- Commentators suggested that the empowerment of women should be given concrete expression (Wereko 1998, 7; and Buor 1998,3; and The Statesman, 26 April 1998). For example, women should have access to vocational skills and creditfacilities, thereby enabling them to cope with prevailing economic hardships. In addition, the Department of Community Development and the Non-Formal Education Department "should be actively supported in their mandate to improve the lot of women through the teaching of employable skillo, edpecially in rural communities" (Wereko 1998, 7). Furthermore, the 31st December Women's Movement and the NCWD were called upon to "intensify their efforts", not only to "step up theenrolment of women at all tiers of the educational system", but also to urge women "to acquire qualifications that will position them favourably in the job market" (Wereko 1998,7).

\section{Conclusion}

Despite its significant import in illustrating gender inequalities and other problems plaguing Ghanaian society, as well as revealing the use of the Internet as an agency of sexual exploitation and abuse, the discourse that informed media commentary was patriarchal. It was Ghanaian women who were called upon to demonstrate, the decline in moral values was seen solely as a female problem, and the conclusion was drawn that women's groups should deal with it alone. It was suggested that a "strong moral fibre of the woman [would] ensure the purification of the moral fibre of society" (Buor $1998,3)$. Schools and churches had the responsibility to "inculcate ... moral education ... healthy lifestyles and behavioural patterns, especially in the girls" (Wereko 1998, 7). The spurious argument was presented that the women had disgraced both themselves and men at large, and that it was women whohad to rectify the situation. Despite a discernible transformation in social awareness, it is worth noting that wife abuse and sexual harassment in the work place are not critically covered by the Ghanaian media, further proof of the existence of patriarchal leanings acting as barriers to meaningful discussions of gender issues.

Within the circles of debate concerned with apportioning blame, the question of innocence was raised. It was suggested that the women wereexercising their inalienable rights by appearing in the nude on the internet. It was noted that in "passing moral judgements we must also keep each individual's rights and liberties in mind" (The Statesman, 26 April 1998, 7). A criticism 
was directed at the newspaper responsible for the mainstream distribution of the pictures, suggesting that Graphic Showbiz" owed the young ladies a duty not to accept the sales from the edition that showed their nude bodies to the Ghanaian public-at least that way the paper's moral indignation will seem justified" (ibid.). One commentator opined that the "excessive" media attention "would only serve to alienate these girls and force them to live as social outcasts", concluding that "under the circumstance, they could be compelled to resort to prostitution for subsistence" (Wereko 1998, 7). One commentator decried the moral judgement being passed on the Ghanaian women, asking several important questions: had the women had been coerced? were they were unsuspecting victims of an international scam? had they acted out of desperation toeam a livelihood or rather, were they expressing their individual liberty? did "the ethos of Ghana's contemporary socio-economic development" playa role? (The Statesman, 26 April 1998, 7). .

\section{Referen}

QWhAkwasi Obrefuour. 1998. "Let's Keep our Africaness." Graphic Showbiz (Accra), 28 May-3 June, 11.

Adams, Paul. 1995. "Ghana Cycle of Dependency." Africa Report (Accra) 40, no. (March-April): 34-37.

Buor, Daniel. 1998. "Saving the Dignity of Womanhood-Time to Demonstrate." The Ghanaian Chronicle (Accra), 29 June3 D June, 3.

Free Press. 1998. "Ghanaian Women Pose Naked on Internet." 22 April-28 April, 1 and 12 .
Goodwill, Clayton. 1998. "Hard Time for African Prostitutes in Europe." New African (London), February, 36-38.

Novicki, Margaret. 1995. "Interview with NanaKonaduAgyemanRawlings." Africa Report (Accra) 40, no. 1 Ganuary-February): 52-54.

Sam, Ato. 1998. "Exposed! Ghanaian Women Trade Sex 'FiliFili."' Free Press (Accra), 24

April-3D April, 1 and 6-7.

The Statesman (Accra), 26 April 1998, 7.

Stranberg Peter. 1998 "Blood, Sweat and

Tears... How Africans Are Exploited in Portugal." New African (London), March, 16-17.

"Traffickers Target Abidjan as Transit Point. Free Press (Accra), 22 April-28 April 1988, 4.

Wereko, Charles. 1998. "Nudity on the Internet: The Way Out." Daily Graphic (Accra), 5 May, 7. ::J

\title{
Refugee Rights: Report on a Comparative Survey
}

\author{
By James C. Hathaway and John A. Dent
}

Toronto: York Lanes Press, 1995; ISBN 1-55014-266-6; 82 pages; $\$ 11.95$

AJ'evisa c()nj;rolsw,te 9,ed. to keep 1' fugees fro\{n reaching an asylum. coul;itry legal? Can asylum-seekers legitimately contest conditions of detention? At what point do refugees have the right to work, or to claim social assistance?

These are among the many issues addressed by Reftgte Rights: Report on a Comparative Survey, a ground-breaking analysi\$of the. buma.n rightS of refu.gees arQundthe WQr1d. W orkmg in col1aQoratiQ with thirty renowned legal experts frQmE.urop fAffl j]!sla,Oceap.ia,NorthAmet.ca,a.t1dLatin America,Professor]a.mesHathaway, Osgoode Hall Law School. York University) and John Dent, Senior Research Associate, International Refugee Rights Project, Osgoode Hall Law School, York University, analyze the international legal instruments that set the human rights of refugees. ;aygroJindi,p,gtl1ei,rap.\#)'Si\$ JAl.'eal?Ufe cballe gt;;s faciJ1g t;;fug es today, I-la.thaway a.nd Dent .have produced a book as valuable tdactiV1StSas to scholars.

Reftgee Rights will provoke debate on the adequacy of the international refugee rights regime. It is essential reading for everyone concerned to counter threats to the human dignity of refugees.

\section{Availableftom:}

Centre for Refugee Studies, York University Suire 333, York Lanes, 4700 Keele Street TbtbfitQ

ON M3j IP3 Fax: (416) 736-5837 -Email: refuge@yorku.ca 